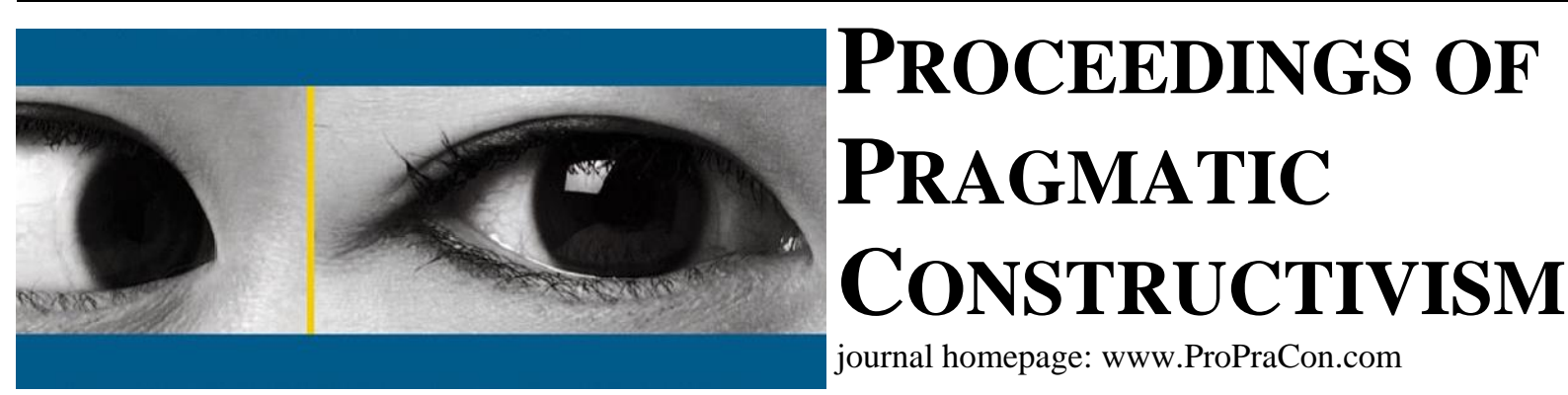

\title{
Making up performance: the construction of "performance” in venture capital firms portfolios
}

\author{
Rafael Heinzelmann \\ NHH Norwegian School of Economics \\ Helleveien 30, 5045 Bergen, Norway; rafael.heinzelmann@nhh.no
}

Keywords: Performance measurement, KPIs, venture capital industry, pragmatic constructivism, actor reality construction.

\section{Extended abstract}

Performance measurement is understood as a corner stone of organizations' accounting and control function (Chenhall, 2003; Merchant \& Van der Stede, 2012). In the wake of the relevance lost debate accounting systems have been criticized for being obsessed with historical financial accounting information making accounting data inadequate for decision making and insufficiently useful for creating a future alertness in organizations (Johnson \& Kaplan, 1987). In the aftermath of this, more strategically-oriented accounting systems fostering on the non-financial dimension of performance, as most prominently presented by the balanced scorecard, gained increasingly attention by organizations and accounting scholars (Ax \& Bjørnenak, 2005; Nørreklit, 2000, 2003). Yet, there is a substantial body of research studying the adoption of MAIs (Management Accounting Innovations) addressing questions of how MAIs such as the Balanced Scorecard travel and change in the course of diffusion and organizational implementation (e.g. Ax \& Bjørnenak, 2005; Jones \& Dugdale, 2002; Qu \& Cooper, 2011). What the literature does not reveal in depth is how do integrated systems for performance measurement and control comprising financial and non-financial KPIs support organizations in handling uncertainty and complexity (Chenhall \& Moers, 2015). In this paper, we aim for exploring performance measurement and control and thus contributing to existing literature by studying how venture capital firms mobilize ideas of performance measurement and control to handle uncertainty and complexity in their investment portfolio. More specifically, we investigate two firms of the venture capital industry that use financial and non-financial indicators to manage their portfolio and make decisions. Consequently, this paper addresses the following research questions: How do venture capital firms use performance measurement to manage their investment portfolios? And how is "performance" constructed in this context?

Exploring how firms from a quite volatile industry use performance measurement is regarded to be interesting from various perspectives: First of all, we know little about the link between uncertainty and performance measurement. Second from a theoretical perspective of ActorReality Construction (ARC) there is little empirical evidence on how organizations construct facts or the factual dimension of accounting and management - facts in the context of our empirical setting, the venture capital industry, are measures used in the performance measurement system (PMS). Particularly, venture capital firms having a big stake in early phase seed investments, are uncertain in the sense that attaching a score or a number to a performance dimension of a portfolio company is maybe not that stable over time and ambiguous. However, doing the exercise of reviewing each portfolio company according to a dashboard-like PMS gives the KPIs, despite of their uncertain nature, a factual character. The PMS numbers allow managers to discuss and evaluate "performance" of the portfolio companies in management meetings as well as to make decisions, on for example, investing additional money, based on the performance facts of the portfolio company. Interestingly, the combination of "hard" and "soft" numbers - thus, financial and non-financial indicators, plays a pivotal role for VC companies in order to be capable to assess "the performance" of the portfolio companies. In other words, it enables venture capital firms to better take into account the particular organizational contexts of portfolio companies. 


\section{References}

Bogt, H. J., Helden, G. J., \& Kolk, B. (2015). Challenging the NPM Ideas About Performance Management: Selectivity and Differentiation in Outcome-Oriented Performance Budgeting. Financial Accountability \& Management, 31(3), 287-315.

Cinquini, L., Tenucci, A., Campanale, C., Passetti, E. (2013). Understanding performance measurement in public organization under pragmatic constructivism. The Actor Reality Perspective Conference.

Dobel, J. P. (1978). The corruption of a state. American Political Science Review, 72(03), 958-973.

Hood, C. (1991). A public management for all seasons?. Public administration, 69(1), 3-19.

Hood, C. (1995). The "New Public Management" in the 1980s: variations on a theme. Accounting, organizations and society, 20(2), 93-109.

Hoskin, K. (2015). What about the box?” Some thoughts on the possibility of 'corruption prevention', and of 'the disciplined and ethical subject. Critical Perspectives on Accounting, 28, 71-81.

Hyndman, N., Liguori, M., Meyer, R. E., Polzer, T., Rota, S., \& Seiwald, J. (2014). The translation and sedimentation of accounting reforms. A comparison of the UK, Austrian and Italian experiences. Critical Perspectives on Accounting, 25(4), 388-408.

Johnston, M. (2015). Making transparency real? Accounting and popular participation in corruption control. Critical Perspectives on Accounting, 28, 97-101.

Lapsley, I. (2008). The NPM agenda: back to the future. Financial accountability \& management, 24(1), 77-96.

Lehman, G. (2010). Perspectives on accounting, commonalities \& the public sphere. Critical Perspectives on Accounting, 21(8), 724-738.

Lynn Jr, L. E. (1998). The new public management: How to transform a theme into a legacy. Public Administration Review, 231-237.

Mitchell, F., Nielsen, L. B., Nørreklit, H., \& Nørreklit, L. (2013). Scoring strategic performance: a pragmatic constructivist approach to strategic performance measurement. Journal of Management \& Governance, 17(1), 5-34.

Morales, J., Gendron, Y., \& Guénin-Paracini, H. (2014). The construction of the risky individual and vigilant organization: A genealogy of the fraud triangle. Accounting, Organizations and Society, 39(3), 170-194.

Nørreklit, L. (2011), “Actors and reality: a conceptual framework for creative governance”, in Jakobsen, M., Johansson, I.-L. and Nørreklit, H. (Eds.), An Actor's Approach to Management Conceptual Framework and Company Practices, Djøf/Jurist- og Økonomforbundet, pp. 7-38.

Nørreklit, L., Nørreklit, H., \& Israelsen, P. (2006). The validity of management control topoi: towards constructivist pragmatism. Management Accounting Research, 17(1), 42-71.

OECD (2007). Performance budgeting in OECD Countries. OECD Publishing.

Robinson, M. (2007). Performance Budgeting: Linking Funding and Results. International Monetary Fund.

Stiglitz, J. E. (1989). The economic role of the state.

Yin, R. (1994). Case study research: Design and methods. Beverly Hills. 